\title{
Interactions Between Breeding Seabird and Pelagic Fish Populations in the Southern Benguela Region
}

\author{
R. W. Furness ${ }^{1}$ and J. Cooper ${ }^{2}$ \\ ${ }^{1}$ Department of Zoology, University of Glasgow, Glasgow G12 8QQ, Scotland \\ ${ }^{2}$ Percy FitzPatrick Institute of African Ornithology, University of Cape Town, Rondebosch 7700, South Africa
}

\begin{abstract}
A bioenergetics model was used to estimate the quantity of pelagic fish eaten and the energy consumed by 3 species of breeding seabirds in the Saldanha Bay fishing ground in the Southern Benguela Region off the west coast of South Africa. The 3 species - jackass penguin Spheniscus dernersus, Cape gannet Sula capensis, and Cape cormorant Phalacrocorax capensis - were estimated to consume a total of 16,500 t of fish $\mathrm{yr}^{-1}$, of which 11,800 t were anchovy Engraulis capensis Gilchrist. This represented a total consumption of $1.3 \times 10^{8} \mathrm{Kj}$. Annual consumption of fish by the 3 seabird species was estimated to represent $30 \%$ of the mean annual catch in the Saldanha Bay fishing ground, based on a mean commercial fishery landing of 55,000 t per year. This figure is similar to that estimated for several other oceans where breeding seabirds and a commercial fishery coexist.
\end{abstract}

\section{INTRODUCTION}

Increasing exploitation of pelagic fish populations throughout the world has led to a focusing of attention on the management of marine ecosystems, rather than of single isolated populations of fish. Predation of pelagic fish by seabirds is one aspect requiring study before fish populations can be effectively managed. Also, development of commercial fisheries can affect seabird populations. For example, seabird numbers decreased by more than an order of magnitude during the development of the Peruvian anchovy Engraulis ringens Jenyns fishery, apparently because, under conditions of reduced fish population size, they were unable to rear sufficient chicks to balance the irregular adult mortality caused by periodic oceanographic perturbations (Jordán and Fuentes, 1966; Nelson, 1978).

Recent studies have shown that seabirds may consume 22 to $29 \%$ of the fish production each year (Wiens and Scott, 1975; Furness, 1978). Detailed investigations of the correlations between seabird and pelagic fish populations in the Benguela region off the west coast of South Africa (Crawford and Shelton, 1978 , in press) have revealed clear relationships between fluctuations in seabird and fish populations, and recent tendencies for overfishing to result in decreasing seabird numbers. Application of a model similar to that of Furness (1978) to the major breeding seabird populations of the Benguela region would therefore be of particular interest in further defining these relationships. In this paper we use a bioenergetics model to estimate the food consumption of the populations of jackass penguins Spheniscus demersus, Cape gannets Sula capensis and Cape cormorants Phalacrocorax capensis in the Saldanha Bay fishing ground (defined in Crawford, 1981a) in the southern Beguela region (Fig. 1). This system is particularly amenable to analysis: the 3 large diurnal species comprise over $95 \%$ of the breeding seabird biomass of the area (JC. unpubl.), and data are available on their diets, breeding biology and foraging ranges (e.g. Cooper, in press), as well as on biomass and size distribution of their fish prey (e.g. Crawford, 1980a, b, $1981 \mathrm{a}, \mathrm{b}, \mathrm{c}, \mathrm{d}, \mathrm{e}, \mathrm{f})$. More bioenergetics equations are now available from studies of a wider variety of species (Kendeigh et al., 1977), further improving the accuracy of these energy budget calculations.

\section{METHODS}

Annual energy requirements of the jackass penguin, Cape gannet and Cape cormorant populations were estimated using a bioenergetics model adapted from 


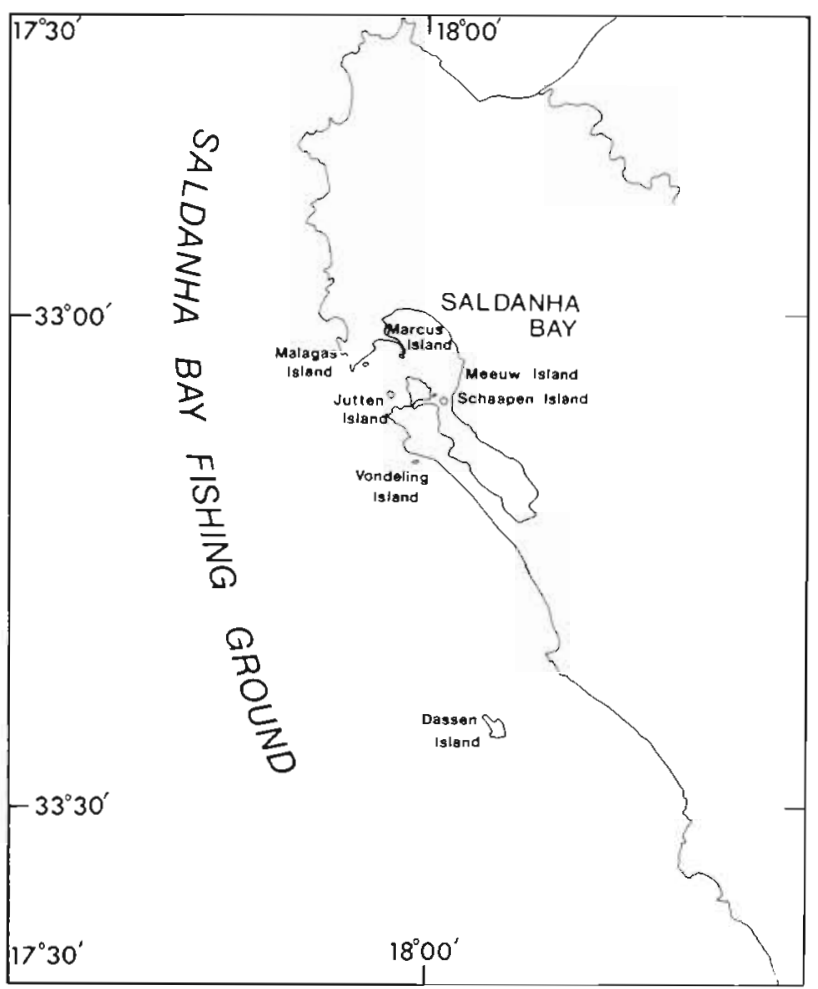

Fig. 1. Saldanha Bay fishing ground, Southern Benguela region, South Africa showing the seabird breeding islands

that described by Furness (1978). In that model a major limitation to the precision of population energy estimates was the wide confidence intervals associated with the bioenergetics equations of Kendeigh (1970). In this study these equations have been replaced by more recent ones based on considerably more extensive data (Kendeigh et al., 1977). Existence energy requirements of full grown birds were estimated using their equations for non-passerines in $15 \mathrm{~h}$ photoperiods and interpolating linearly between the value at $0^{\circ} \mathrm{C}$ $\left(M=17.33 W^{0.5444}\right)$ and $30^{\circ} \mathrm{C}\left(M=4.47 W^{0.6637}\right)$, where $M=$ metabolic requirement in $\mathrm{Kj} \mathrm{day}^{-1} ; W=$ mass in $\mathrm{g}$. For flapping flight, metabolic costs are increased by $M=1.395 W^{0.67} \mathrm{Kj} \mathrm{h}^{-1}$ over existence requirements, while gliding flight is estimated to be an additional $M=2.186 W^{0.7347} \mathrm{Kj} \mathrm{d}^{-1}$. Energetic costs of underwater and surface swimming are taken to be the same as flapping and gliding flight, respectively, and we have had to assume that the thermal insulation of the birds is adequate to allow us to ignore any differences between water and air temperatures to which the birds are exposed while foraging. Chick daily energy requirements are obtained from $M=5.661$ $W^{0.814} \mathrm{Kj} \mathrm{d}^{-1}$ (Kendeigh et al., 1977). Energy costs of moult are calculated assuming that this increases daily existence metabolism by a factor of 10 to $50 \%$ depending on the rate of moult (Kendeigh et al., 1977, p. 177).
Energy costs of egg production are given by $M=5.439$ (egg weight) $\times \frac{100}{73} \mathrm{Kj} \mathrm{egg}^{-1}$ and all energy costs were multiplied by 1.25 to account for digestive losses (Furness, 1978).

Mean monthly air temperatures for the area were taken from Schulze (1972). Chick masses were input as growth equations fitted according to the method of Ricklefs (1967), using data from field studies by members of the FitzPatrick Institute. Numbers of breeding adults were obtained from colony counts published in Rand (1963), Frost et al. (1976), Crawford and Shelton (1978), Crawford et al. (in press a, b) and JC (unpubl.). Numbers in immature age classes were estimated by constructing a life table for a stable population using available or estimated values of adult survival, age at first breeding, clutch size, hatching and fledging success. Breeding biology statistics were taken from published literature or unpublished data belonging to the FitzPatrick Institute. As a first approximation it was assumed that all members of the populations remained within the Saldanha Bay fishing ground throughout the year. Where counts of non-breeders showed deviations from this assumption owing to migrations outside the breeding season, estimates obtained from life tables have been replaced by field estimates of numbers. This was necessary only for Cape cormorants, where numbers in Saldanha Bay often greatly exceeded expectation (JC, unpubl.) due presumably to immigration of non-breeders from further afield into this sheltered area.

\section{MODEL INPUT}

Counts of moulting jackass penguins at Saldanha Bay islands in 1977-1978 gave a population estimate of 52,400 adults, of which 6,857 were 1 yr old (JC, unpubl.). Assuming that all members of the population moulted within Saldanha Bay, and confounding effects of population growth or decrease can be ignored, this implies an annual adult mortality of $13 \%$, similar to the mortality rate of the yellow-eyed penguin Megadyptes antipodes (13\%; Lack, 1966) and of the little penguin Eudyptula minor (14\%; Reilly and Cullen, 1979). Although Jackson et al. (1976) assume that jackass penguins first breed when 2 yr old, very few have been recorded breeding before three years of age ( $R$. M. Randall, pers. comm.; JC, unpubl.). Taking an age of first breeding of $3 \mathrm{yr}$ and assuming all older birds breed, a mean of 1.8 eggs laid per pair per year, $70 \%$ hatching and $40 \%$ fledging success (Frost et al., 1976; Jackson et al., 1976) a first year survival of $68 \%$ is required to balance an adult mortality rate of $13 \%$. This seems quite within the bounds of expectation, so 
Table 1. Demographic data and life tables used to estimate seabird population sizes from census data (see text for explanation)

\begin{tabular}{|c|c|c|c|}
\hline Category & Jackass penguin & Cape gannet & Cape cormorant \\
\hline Breeding adults & 1,000 & 1,000 & 1,000 \\
\hline Eggs laid & 900 & 500 & 1,500 \\
\hline Chicks hatched & 630 & 400 & 1,050 \\
\hline Chicks fledged & 252 & 380 & 735 \\
\hline Recruits required (= adults dying) & 130 & 100 & 200 \\
\hline $4 \mathrm{yr}$ olds & - & 100 & - \\
\hline 3 yr olds & 130 & 111 & 200 \\
\hline 2 yr olds & 149 & 123 & 250 \\
\hline 1 yr olds & 171 & 137 & 313 \\
\hline Necessary first year & $\underline{171}$ & $\underline{137}$ & 313 \\
\hline survival & $\overline{252}$ & $\overline{380}$ & $\overline{735}$ \\
\hline \multicolumn{4}{|l|}{ Assumed first year } \\
\hline survival & $68 \%$ & $36 \%$ & $43 \%$ \\
\hline \multirow{2}{*}{$\begin{array}{c}\text { Breeding pairs: Saldanha } \\
\text { Dassen }\end{array}$} & 21,200 & 10,000 & 6,000 \\
\hline & 28,000 & 0 & 10,000 \\
\hline \multirow[t]{2}{*}{ Immatures: } & 10,000 & 7,400 & 18,000 \\
\hline & 13,200 & 0 & 3,500 \\
\hline
\end{tabular}

the numbers of pre-breeders and breeding pairs have been calculated from this life table (Table 1). The number of adult jackass penguins on Dassen Island was estimated at 70,000 (Frost et al., 1976) which is equivalent to 28,000 breeding pairs assuming the same life table statistics (Table 1).

The Saldanha Bay Cape gannet population was estimated to be 39,000 adults in 1956 (Rand, 1963), 34,000 in 1967, 32,000 in 1969 (Crawford and Shelton, 1978), 16,000 breeding birds in 1977-1978 (JC, unpubl.) and 32,000 adults in November 1978 (Crawford et al., in press a). Assuming an age of first breeding of $4 \mathrm{yr}$, adult survival of $90 \%$ fledging success (Jarvis, 1971; Nelson, 1978) a plausible first year survival of $36 \%$ is required to balance adult losses. The Saldanha Bay gannet population of the 1970 s was estimated to number 27,400 birds comprising, according to these life table statistics, 10,000 breeding pairs and 7,400 immatures.

Rand (1960 a, 1963) calculated a population estimate of 87,400 Cape cormorants on the islands in Saldanha
Bay in 1956. Cooper (unpubl.) estimated that 11,880 Cape cormorants bred on the Saldanha Bay islands in 1977-1978, but also counted up to 60,000 roosting nonbreeders at Marcus Island alone. Rand's figure for Dassen Island was 23,500 adults in 1956, while Crawford et al. (in press b) counted 13,800 nests in 1978 on Dassen Island. From their figures we have taken the values presented in Table 1 to represent the populations in the 1970 s. We assume an age of first breeding of $3 \mathrm{yr}$ as adult plumage is acquired when $2 \mathrm{yr}$ old (Berry, 1976), an adult survival of $80 \%$, a mean clutch size of 2.8 with $8 \%$ of pairs losing and replacing clutches so 3.0 eggs are laid per pair per year, $70 \%$ hatching and $70 \%$ fledging success (Berry, 1976 and estimates based on data from studies of other species of cormorant). With these data, constructing a life table requires a $43 \%$ survival of first year birds to balance adult mortality.

Species statistics required for energetics calculations (Table 2) were extracted from Rand (1960a, b), Jarvis (1971), Berry (1976), Cooper (1977, 1978, unpubl.), Nel-

Table 2. Species statistics used in model (see text for sources and further details)

\begin{tabular}{|c|c|c|c|c|c|c|c|c|c|c|c|c|}
\hline \multirow[t]{2}{*}{ Species } & \multirow{2}{*}{$\begin{array}{c}\text { Mean } \\
\text { adult } \\
\text { mass } \\
(\mathrm{g})\end{array}$} & \multirow{2}{*}{$\begin{array}{c}\text { Mean } \\
\text { egg } \\
\text { mass } \\
(g)\end{array}$} & \multirow{2}{*}{$\begin{array}{l}\text { Mean } \\
\text { incu- } \\
\text { bation } \\
\text { period } \\
\text { (d) }\end{array}$} & \multirow{2}{*}{$\begin{array}{c}\text { Mean } \\
\text { laying } \\
\text { date }\end{array}$} & \multirow{2}{*}{$\begin{array}{c}\text { Standard } \\
\text { deviation } \\
\text { of laying } \\
\text { dates } \\
\text { (d) }\end{array}$} & \multirow{2}{*}{$\begin{array}{l}\text { Chick growth } \\
\text { input data }\end{array}$} & \multicolumn{2}{|c|}{ Moult } & \multicolumn{4}{|c|}{ Mean $h$ foraging $d^{-1}$} \\
\hline & & & & & & & $\begin{array}{l}\text { duration } \\
\text { (d) }\end{array}$ & $\begin{array}{c}\text { cost } \\
(\mathrm{xEM})\end{array}$ & diving & $\begin{array}{l}\text { swimm- } \\
\text { ing }\end{array}$ & $\begin{array}{l}\text { glid- } \\
\text { ing }\end{array}$ & $\begin{array}{l}\text { flapp- } \\
\text { ing }\end{array}$ \\
\hline $\begin{array}{l}\text { Jackass } \\
\text { Penguin }\end{array}$ & 2994 & 106 & 38 & $\begin{array}{l}\text { uniform } \\
\text { out th }\end{array}$ & $\begin{array}{l}\text { n through- } \\
\text { he year }\end{array}$ & $W=2900 e^{-3.6958 e^{-0.0449}}$ & 18 & 0.5 & 0.5 & 5 & 0 & 0 \\
\hline $\begin{array}{l}\text { Cape } \\
\text { Gannet }\end{array}$ & 2649 & 98 & 43 & 15 Nov. & 20 & $W=3300 e^{-3.825 e^{-0.0541}}$ & 150 & 0.1 & 0 & 0 & 6 & 2 \\
\hline $\begin{array}{l}\text { Cape } \\
\text { Cormorant }\end{array}$ & 1219 & 38 & 23 & $13 \mathrm{Dec}$ & 20 & $W=1500 e^{-4.0558 e^{-0.0795 t}}$ & 150 & 0.1 & 0.25 & 3 & 0 & 1.25 \\
\hline
\end{tabular}


son (1978) and observations of the foraging activity budgets of these species made by the authors. Of the input data in Table 2 the estimated hours of each daily foraging activity are poorly known. These may be in error by as much as $\pm 50 \%$. Egg laying dates were assumed to be normally distributed in Cape gannets and Cape cormorants but are clearly not in the jackass penguin population, where laying occurs with irregular peaks several times of year (Cooper, 1980; Randall and Randall, in press). For this model jackass penguin laying was taken to occur uniformly throughout the year.

\section{ENERGY COSTS AND FISH CONSUMPTION}

Estimated annual energy costs of adult existence, feeding activity (additional to existence costs), moult, egg production and chick daily energy budget (growth plus existence) were calculated for the populations of each species in Saldanha Bay (Table 3) and at Dassen Island. Adult existence costs represented 51 to $72 \%$ of the total population budget, while costs of moult and egg production together accounted for less than $3 \%$ of any species' total (Table 3 ). A sensitivity analysis (Furness, 1978) indicated that in this model population energy estimates were particularly sensitive to errors in estimates of seabird population size, rather less so to errors in the input hours of flapping flight or swimming under water per day, while the likely errors in other parameters or the model equations themselves all contribute relatively little to the total inaccuracy of the output.

Total population annual energy requirements need to be increased by a factor of 1.25 to allow for a digestive efficiency of $80 \%$. The resulting annual consumption by each population is shown in terms of energy in Table 4.

Energy requirements can be converted to fish consumption from a knowledge of the diets of these species in the Saldanha Bay area in the period 1977-1979 (Crawford and Shelton, in press; Cooper, in press). Percentage composition is given in terms of numbers of fish of each species. Individuals of demersal species in the diet tend to be larger than the pelagic ones but have a considerably lower energy value, so the average energetic content of a fish of each species is likely to be similar. For this reason we have simply converted energy intake to grams of fish in proportion to the frequency of each species in the diet (averaged over the year), assuming that $1 \mathrm{~g}$ of fish is equivalent to $8 \mathrm{Kj}$. This is approximately the energy value of anchovy (Cooper, 1978), the main species in the diet of all 3 seabirds. Diets and consumption figures are given in Table 5. Pelagic fish species, particularly anchovy, predominate. The category 'other species' consists

Table 3. Saldanha Bay seabird population energy requirements for adult existence, additional costs of foraging, moult, egg production, and chick existence plus growth. Values are annual totals before allowance has been made for digestive efficiency

\begin{tabular}{|c|c|c|c|c|c|c|}
\hline \multirow[t]{2}{*}{ Category } & \multicolumn{2}{|c|}{ Jackass Penguin } & \multicolumn{2}{|c|}{ Cape Gannet } & \multicolumn{2}{|c|}{ Cape Cormorant } \\
\hline & $\begin{array}{l}\text { Population } \\
\text { requirement } \\
\quad\left(\mathrm{kj} \times 10^{8}\right)\end{array}$ & $\begin{array}{l}\text { Percentage } \\
\text { of total } \\
\text { population } \\
\text { requirement }\end{array}$ & $\begin{array}{l}\text { Population } \\
\text { requirement } \\
\quad\left(\mathrm{kj} \times 10^{8}\right)\end{array}$ & $\begin{array}{l}\text { Percentage } \\
\text { of total } \\
\text { population } \\
\text { requirement }\end{array}$ & $\begin{array}{l}\text { Population } \\
\text { requirement } \\
\quad\left(\mathrm{kj} \times 10^{8}\right)\end{array}$ & $\begin{array}{l}\text { Percentage } \\
\text { of total } \\
\text { population } \\
\text { requirement }\end{array}$ \\
\hline Adult existence & 229.4 & 71.4 & 101.9 & 50.7 & 72.1 & 63.6 \\
\hline Adult foraging & 62.4 & 19.4 & 72.7 & 36.1 & 32.3 & 28.5 \\
\hline Chick existence + growth & 24.6 & 7.6 & 22.2 & 11.0 & 6.2 & 5.4 \\
\hline Moult & 4.9 & 1.5 & 4.3 & 2.1 & 2.8 & 2.5 \\
\hline Egg production & 0.4 & 0.1 & 0.1 & 0.1 & 0.05 & 0.0 \\
\hline Population total & 321.7 & $100 \%$ & 201.2 & $100 \%$ & 113.4 & $100 \%$ \\
\hline
\end{tabular}

Table 4. Annual energy consumption by seabird populations in the Saldanha Bay fishing ground

\begin{tabular}{|lcr|c|}
\hline Species & \multicolumn{2}{c|}{$\begin{array}{c}\text { Annual energy consumption }\left(\mathrm{kJ} \times 10^{8}\right) \\
\text { Saldanha fishing ground } \\
\text { (total) }\end{array}$} \\
\hline Jackass Penguin & Saldanha Bay islands & 424.9 & 827.0 \\
Cape Gannet & 402.1 & 0.0 & 251.5 \\
Cape Cormorant & 251.5 & 94.4 & 236.2 \\
Total & 141.8 & 519.3 & 1314.7 \\
\hline
\end{tabular}


Table 5. Diet and consumption of major seabird populations in the Saldanha Bay fishing ground

\begin{tabular}{|c|c|c|c|c|c|c|c|}
\hline \multirow[t]{2}{*}{ Species } & \multicolumn{2}{|c|}{ Jackass Penguin } & \multicolumn{2}{|c|}{ Cape Gannet } & \multicolumn{2}{|c|}{ Cape Cormorant } & \multirow{2}{*}{$\begin{array}{c}\text { Total } \\
\text { Tonnes } \\
\text { consumec } \\
\text { per year }\end{array}$} \\
\hline & $\begin{array}{l}\text { Diet } \\
(\%)\end{array}$ & $\begin{array}{l}\text { Tonnes } \\
\text { consumed } \\
\text { per year }\end{array}$ & $\begin{array}{l}\text { Diet } \\
(\%)\end{array}$ & $\begin{array}{c}\text { Tonnes } \\
\text { consumed } \\
\text { per year }\end{array}$ & $\begin{array}{l}\text { Diet } \\
(\%)\end{array}$ & $\begin{array}{l}\text { Tonnes } \\
\text { consumed } \\
\text { per year }\end{array}$ & \\
\hline Anchory & 80 & 8,270 & 60 & 1,887 & 55 & 1,624 & 11,781 \\
\hline Round Herring & 10 & 1,034 & 0 & 0 & 30 & 886 & 1,920 \\
\hline Pilchard & 5 & 517 & 15 & 472 & 5 & 148 & 1,137 \\
\hline 'Other species' & 5 & 517 & 25 & 786 & 10 & 295 & 1,598 \\
\hline Total & & 10,338 & & 3,144 & & 2,953 & 16,435 \\
\hline
\end{tabular}

largely of demersal species scavenged from trawlers by Cape gannets (Sinclair, 1978; Cooper, in press) and squid eaten by jackass penguins.

\section{DISCUSSION}

Cooper (in press) showed that most breeding seabirds in the southern Benguela region fed close to the breeding colonies and coastline; 85,95 and $70 \%$ of jackass penguins, Cape cormorants and Cape gannets were observed less than $50 \mathrm{~km}$ from the coast; 75,80 and $75 \%$ respectively were found to be within $50 \mathrm{~km}$ of their Saldanha breeding colonies. It seems reasonable to compare the fish consumption statistics (Table 5) with the pelagic fish catches and stocks of the Saldanha fishing ground, since relatively few of the seabirds appear to travel beyond the limits of this region to feed. The maximum lengths of fish recorded from stomach samples of the Cape gannet, jackass penguin and Cape cormorant are $350 \mathrm{~mm}$ (Rand, 1959), $270 \mathrm{~mm}$ (Matthews, 1961) and $260 \mathrm{~mm}$ (Davies, 1956). Very few pelagic fish in South African waters exceed these sizes (Table 5 in Crawford and Shelton, 1978) so the majority of the pelagic fish are suitable for consumption by these seabirds. The total annual consumption of $16,500 \mathrm{t}$ of fish by the 3 species in the Saldanha fishing ground represents a significant proportion compared to that taken by pelagic fishery. Almost all consumption comprises pelagic species, particularly anchovy Engraulis capensis Gilchrist (11,800 t). Since the commercial fishery has been working at or above the maximum sustainable yield for most of the pelagic species (Stander and Le Roux, 1968; Baird, 1975; Centurier-Harris, 1977; Newman et al., 1979; Crawford, 1980a, 1981a) a reduction in consumption by seabirds might lead to an increased fishing yield. However, this cause and effect relationship remains unproven. Between 1971 and 1976 catches of pelagic fish in the Saldanha Bay fishery area varied between 12,100 and 85,600 , averaging $55,000 \mathrm{t}$ (Crawford, 1979) so the seabird consumption in the same period equalled the fish landings in $1 \mathrm{yr}$ and averaged $30 \%$ of the mean catch.

Although some South African pelagic fish species show distinct migrations in relation to age, and occur more frequently in particular coastal areas, the seasonal pattern in commercial catch per unit effort is one reflecting a relatively constant resource within and between areas (Crawford, 1980a), particularly in the Saldanha fishing ground where the pelagic fish populations, the seabirds' food resource, show a high temporal stability (Crawford and Shelton, 1978). Between 1971 and 1976 the South African mixed-species pelagic fishery landings comprised $59 \%$ anchovy, $22 \%$ pilchard Sardinops ocellata Pappe, $11 \%$ mackerel Scomber japonicus Houttuyn, $4 \%$ round herring Etrumeus teres Whitehead, and $4 \%$ other species in terms of biomass (Crawford, 1979). Assuming that the frequencies of these species are the same in the Saldanha fishing ground as for the whole South African fishery, one might expect the consumption by seabirds to reflect these proportions, since their diets often appear to reflect relative abundance of pelagic species (Jarvis, 1971; Crawford and Shelton, 1978). To examine this we have used the Virtual Population Analyses (VPA's) (Everhart and Youngs, 1981) for each fish species in the South African pelagic fishery and assumed that $13 \%$ of this population is present in the Saldanha Bay fishing ground. This figure is derived from the fact that $13.7 \%$ of the 1971-1976 catches and $15.7 \%$ of the fishing effort occurred in the Saldanha Bay fishing ground. The catch per unit effort in this area therefore represents $92 \%$ of the average for the whole South African pelagic fishery, suggesting that the proportion of the fish populations in this area is slightly less than the proportion of the catches made there (i.e. less than $13.7 \%$ ).

Natural mortality is approximately equal to fishing mortality for anchovy, pilchard and round herring (Newman and Crawford, 1980). Taking anchovy, and allowing for a constant annual natural mortality of 0.8 VPA indicates an average population of $50,700 \mathrm{t}$ in the Saldanha Bay fishing ground between 1971 and 1976. An average consumption of $11,800 \mathrm{t}$ by the seabirds 
represents an annual cropping of $23 \%$ of the anchovy biomass by the seabirds. VPA for the pilchard population, assuming constant annual natural mortality of 0.5 . suggests a biomass of 29,000 $\mathrm{t}$ in the Saldanha Bay fishing ground. Seabird consumption of $1,137 \mathrm{t}$ represents predation of $4 \%$ of this population. VPA for the round herring, assuming constant annual natural mortality of 0.5 , suggests a biomass of $8,000 \mathrm{t}$ in the Saldanha Bay fishing ground. Seabird consumption totals $1,920 t$, or $24 \%$ of this estimated population. Seabird predation on horse mackerel, mackerel and lanternfish Lampanyctodes hectoris Günther populations is negligible. The first 2 species are mesopelagic for most of their life while the last is only present in small numbers (Crawford, 1980b, 1981e, f).

The impact of seabird predation on each fish population appears to differ quite widely. Possibly, pilchard are less available to seabirds than are anchovy and round herring, but it is likely that the main cause of this apparent difference is the relative abundance of the fish populations in the Saldanha Bay fishing ground compared to other South African fishing areas. If pilchard are relatively scarce and anchovy and round herring relatively more abundant in the Saldanha Bay fishing ground, then the seabirds may not be selecting between species. However, there is good evidence that seabirds breed more successfully when able to select a diet with a high energy value (Harris and Hislop, 1978), and tend to feed their young on a diet with a higher energy value than that taken by breeding adults or immatures (Furness and Hislop, 1981).

If fishing mortality equals natural mortality (Newman and Crawford, 1980) and seabird consumption averaged $30 \%$ of the fishery catch between 1971 and 1976, then seabird predation was responsible for about $15 \%$ of total fish mortality. As seabirds consumed about $20 \%$ of anchovy and round herring biomass each year this implies an annual production to biomass $(P: \vec{B})$ ratio of slightly over 1 for the pelagic fish stocks. This would be compatible with $\mathrm{P}: \overline{\mathrm{B}}$ ratios determined for a variety of, primarily freshwater, fish species (Chapman, 1978; Craig, 1980).

Schaefer (1970) estimated from field data that each Peruvian seabird eats on average $430 \mathrm{~g}$ of anchovy each day. This represented an annual consumption through the early $1960 \mathrm{~s}$ of about $2.8 \times 10^{6} \mathrm{t}$ by the seabird population. At the same time the fishery landed $8 \times 10^{6} \mathrm{t} \mathrm{yr}^{-1}$ and accounted for about $60 \%$ of the total fish mortality (Schaefer, 1970), so the seabirds were probably responsible for about $20 \%$ of the fish mortality

In the North Sea, overfishing of large valuable fish has led to a decrease in mean fish size, and increases in population numbers of the small and unexploited species (Anderson and Ursin, 1977). This trend is likely to have been beneficial to most seabirds, which tend to feed on the smaller fish, and in most cases their populations have increased during the 20th century. Obtaining an accurate estimate of the quantity of fish they consume has been limited by a lack of adequate data, particularly concerning species' foraging ranges from breeding colonies and their activity budgets, but also fish stock densities and productivities, and sufficiently precise bioenergetics equations for calculating costs of existence and flight metabolism. Taking the data available, Furness (1978) estimated that the seabirds of 1 colony in Shetland consumed $29 \%$ of the fish production within a $45 \mathrm{~km}$ radius of the colony, with $95 \%$ confidence limits of 11 and $63 \%$. A similar earlier model applied to the seabird populations of coastal Oregon suggested that these birds consume $22 \%$ of the fish production each year (Wiens and Scott, 1975).

Thus data now available for 4 different marine ecosystems which support both seabirds and a commercial fishery suggest that seabirds consume from 17 to $29 \%$ of annual fish production.

Since the breeding seabird populations of the Saldanha Bay fishing ground consume about one fifth of the anchovy/pilchard/round herring production each year it is not surprising that Crawford and Shelton (1978) found a close correlation between fluctuations in fish stocks and seabird breeding populations. The implications for fisheries management and seabird conservation are obvious, since commercial fisheries, seabirds, predatory fish such as snoek Thyrsites atun, and Cape fur seals Arctocephalus pusillus all depend on the pelagic fish stocks for their existence.

Acknowledgements. We thank Dr. R. J. M. Crawford for providing us with VPA estimates of fish stocks. R. W. Furness acknowledges financial support from The Royal Society of Great Britain and the African Seabird Group towards his travel costs to visit South Africa and thanks Professor W. R. Siegfried for providing facilities for this work in the Percy FitzPatrick Institute, University of Cape Town. J. Cooper acknowledges financial and other support received from the South African Nature Foundation, the South African National Foundation for the Conservation of Coastal Birds, the Sea Fisheries Institute and the Department of Environment Affairs of South Africa, and the University of Cape Town. We thank Drs. R. J. M. Crawford, D. C. Duffy and B. L. Furness for constructive criticism of the text.

\section{LITERATURE CITED}

Anderson, K. P., Ursin, E. (1977). A multispecies extension to the Beverton and Holt theory of fishing, with accounts of phosphorus circulation and primary production. Meddr Danm. Fisk.-og. Havunders N. S. 7: 319-435

Baird, D. (1975). The South African mackerel: its biology and fishery. S. Afr Shipp. News Fish. Ind. Rev. 30(6): 46-51

Berry, H. H. (1976). Physiological and behavioural ecology of the Cape Cormorant, Phalacrocorax capensis. Madoqua $9(4): 5-55$ 
Centurier-Harris, O. M. (1977). Estimates of size and interaction of the South African anchovy and pilchard populations. M.Sc. thesis, University of Cape Town

Chapman, D. W. (1978). Production in fish populations. In Gerking, S. D. (ed.) Ecology of freshwater fish production. Blackwell, Oxford, pp. 5-25

Cooper, J. (1977). Energetic requirements for growth of the Jackass Penguin. Zool. Afr 12: 201-213

Cooper, J. (1978). Energetic requirements for growth and maintenance of the Cape Gannet (Aves: Sulidae). Zool. Afr. 13: 305-317

Cooper, J. (1980). Breeding biology of the Jackass Penguin with special reference to its conservation. Proc. IV PanAfr. Orn. Congr.: 227-231

Cooper, J. (in press). Changes in resource division among four breeding seabirds in the Benguela upwelling system. Proc. V Pan-Afr. Orn. Congr.

Craig, J. F. (1980). Growth and production of the 1955 to 1972 cohorts of perch, Perca fluviatilis L., in Windermere. J. Anim. Ecol. 49: 291-315

Crawtord, R. J. M. (1979). Implications of recruitment, distribution and availability of stocks for management of South Africa's Western Cape purse-seine fishery. Ph.D. thesis, University of Cape Town

Crawford, R. J. M. (1980a). Seasonal patterns in South Africa's Western Cape purse-seine fishery. J. Fish Biol. 16: 649-664

Crawford, R. J. M. (1980b). Occurrence and distribution of lanternfish Lampanyctodes hectoris catches in the South African purse-seine fishery, 1968-1976. Fish, Bull. S. Afr. 13: $111-136$

Crawford, R. J. M. (1981a). Catch per standard-boat-day and deployment of effort in the South African purse-seine fishery, 1964-1976. Investl Rep. Sea Fish. Inst. S. Afr. 122: $1-24$

Crawford, R. J. M. (1981b). Distribution, availability and movements of pilchard Sardinops ocellata off South Africa, 1964-1976. Fish. Bull. S. Afr. 14: 1-46

Crawford, R. J. M. (1981c). Distribution, availability and movements of anchovy Engraulis capensis off South Africa, 1964-1976. Fish. Bull. S. Afr 14: 51-94

Crawford, R. J. M. (1981d). Distribution, availability and movements of round herring Etrumeus teres off South Africa, 1964-1976. Fish. Bull. S. Afr 14: 141-181

Crawford, R. J. M. (1981e). Distribution and availability of horse mackerel Trachurus trachurus off South Africa, 1964-1976. Fish. Bull. S. Afr 15: 1-41

Crawford, R. J. M. (1981f). Distribution, availability and movements of mackerel Scomber japonicus off South Africa, 1964-1976. Fish. Bull. S. Afr. 15: 123-166

Crawford, R. J. M., Shelton, P. A. (1978). Pelagic fish and seabird interrelationships off the coasts of South West and South Africa. Biol. Conserv. 14: 85-109

Crawford, R. J. M., Shelton, P. A. (in press). Population trends for some southern African seabirds related to fish availability. In: Cooper, J. (ed.) Proceedings of the Symposium on Birds of the Sea and Shore, 1979. African Seabird Group, Cape Town

Crawford, R. J. M., Shelton, P. A., Cooper, J. (in press a) Distribution, population size and conservation of the Cape Gannet. Fish. Bull. S. Afr

Crawford, R. J. M., Shelton, P. A., Cooper, J., Brooke, R. K. (in press $b$ ). Distribution, population size and conservation of the Cape Cormorant. Fish. Bull. S. Afr.

Davies, D. H. (1956). The South African pilchard (Sardinops ocellata) and maasbanker (Trachurus trachurus): bird pre- dators, 1954-1955. Investl Rep. Div. Fish. Un. S. Afr 23: $1-40$

Everhart, W H., Youngs, W. D. (1981). Principles of fishery science, Cornell University Press, Ithaca

Frost, P. G. H., Siegfried, W R., Cooper, J. (1976). Conservation of the jackass penguin (Spheniscus demersus [L.]). Biol. Conserv. 9: 79-99

Furness, R. W. (1978). Energy requirements of seabird communities: a bioenergetics model. J. Anim. Ecol. 47: 39-53

Furness, R. W., Hislop, J. R. G. (1981). Diets and feeding ecology of Great Skuas Catharacta skua during the breeding season in Shetland. J. Zool., Lond. 195: 1-23

Harris, M. P., Hislop, J. R. G. (1978). The food of young Puffins Fratercula arctica. J. Zool., Lond. 185: 213-236

Jackson, F., Siegfried, W. R., Cooper, J. (1976). A simulation model for the population dynamics of the Jackass Penguin. Trans. R. Soc. S. Afr. 42: 11-21

Jarvis, M. J. F. (1971). Interactions between man and the South African Gannet Sula capensis. Ostrich 8 (Suppl.): $497-513$

Jordán, R., Fuentes, H. (1966). Las poblaciones de aves guaneras y su situación actual. Inf. Inst. Mar. Perú-Callao 10: $1-31$

Kendeigh, S. C. (1970). Energy requirements for existence in relation to size of bird. Condor 72: 60-65

Kendeigh, S. C., Dol'nik, V. R., Gavrilov, V. M. (1977). Avian energetics. In: Pinowski, J., Kendeigh, S. C., (eds.) Granivorous birds in ecosystems. Cambridge University Press, Cambridge, pp. 129-204

Lack, D. (1966). Population studies of birds, Clarendon Press, Oxford

Matthews, J. P. (1961). The pilchard of South West Africa Sardinops ocellata and the maasbanker Trachurus trachurus. Bird predators, 1957-1958. Investl Rep. Mar. Res. Lab. S.W. Afr. 3: 1-35

Nelson, J. B. (1978). The Sulidae Gannets and Boobies, Oxford University Press, Oxford

Newman, G. G., Crawford, R. J. M. (1980). Population biology and management of mixed-species pelagic stocks off South Africa. Rapp. P.-v. Réun. Cons. int. Explor. Mer 177 : 279-291

Newman, G. G., Crawford, R. J. M., Centurier-Harris, O. M. (1979). Fishing effort and factors affecting vessel performance in the South African purse-seine fishery, 1964-1972. Investl Rep. Sea Fish. Brch S. Afr. 120: 1-34

Rand, R. W. (1959). The biology of guano-producing seabirds. The distribution, abundance and feeding habits of the Cape Gannet, Morus capensis, off the southwestern coast of the Cape Province. Investl Rep. Div. Fish. Un. S. Afr. 39: $1-36$

Rand, R. W. (1960a). The biology of guano-producing seabirds. The distribution, abundance and feeding habits of the Cape Penguin, Spheniscus demersus, off the southwestern coast of the Cape Province. Investl Rep. Div. Fish. Un. S. Afr. 41: 1-28

Rand, R. W. (1960b). The biology of guano-producing seabirds. 3 . The distribution, abundance and feeding habits of the cormorants Phalacrocoracidae off the southwest coast of Cape Province. Investl Rep. Div. Fish. Un. S. Afr. 42: $1-32$

Rand, R. W. (1963). The biology of guano-producing seabirds. 4. Composition of colonies on the Cape Islands. Investl Rep. Div. Fish. Un. S. Afr. 43: 1-32

Randall, R. J. M., Randall, B. M. (in press). The annual cycle of the Jackass Penguin Spheniscus demersus at St. Croix Island, South Africa. In: Cooper, J. (ed.) Proceedings of the 
symposium on birds of the sea and shore, 1979. African Seabird Group, Cape Town

Reilly, P. N., Cullen, J. M. (1979). The little penguin Eudyptes minor in Victoria 1: Mortality of adults. Emu 79: 97-102

Ricklefs, R. E. (1967). Relative growth, body constituents and energy content of nestling Barn Swallows and Redwinged Blackbirds. Auk 84: 560-570

Schaefer, M. B. (1970). Bird and anchovies in the Peru Current - dynamic interactions. Trans. Am. Fish. Soc. 99: 461-467

Schulze, B. R. (1972). South Africa. In: Griffiths, J. F. (ed.)
Climates of Africa. World survey of climatology 10: 501-588 (Elsevier Amsterdam)

Sinclair, J. C. (1978). Birds of a trawling voyage. Bokmakierie 30: $12-16$

Stander, G. H., Le Roux, P. J. (1968). Notes on fluctuations of the commercial catch of the South African pilchard (Sardinops ocellata) 1950-1965. Investl Rep. Div. Fish. Un. S. Afr. 65 : 1-14

Wiens, J. A., Scott, J. M. (1975). Model estimation of energy flow in Oregon coastal seabird populations. Condor 77 : 439-452

This paper was presented by Professor J. G. Field; it was accepted for printing on February 8, 1982 